13Pheasant, D. R. and J. T. Andrews. 1973. Wisconsin glacial chronology and relative sea level movements, Narpaing Fiord, Broughton Island area, eastern Baffin Island, N.W.T. Canadian Journal of Earth Science, 10: 1621-41.

${ }^{14}$ Brassard, G. R. 1971. The mosses of northern Ellesmere Island, Arctic Canada, I: ecology and phytogeography, with an analysis for the Queen Elizabeth Islands. The Bryologist, 74(3): 233-311.

${ }^{15}$ Hattersley-Smith, G. and A. Long. 1967. Postglacial uplift at Tanquary Fiord, Northern Ellesmere Island, Northwest Territories. Arctic, 20: 255-60.

${ }^{16}$ Lasca, N. P. 1966. Postglacial delevelling in Skeldal, northeast Greenland. Arctic, 19: 349-53.

17Washburn, A. L. and M. Stuiver. 1962. Radiocarbon-dated postglacial delevelling in northeast Greenland and its implications. Arctic, 15: 66-73.

${ }^{18}$ Crary, A. P. 1960 . Arctic ice island and ice shelf studies, Part II. Arctic, 13: 32-50.

\section{On a Polynya in Makinson Inlet}

A polynya was observed three kilometres south of Hook Glacier in the northwest arm of Makinson Inlet in May 1973 (Fig. 1). Because of a combination of rough ice, soft snow and a spell of high winds it was only possible to occupy four stations in the arm: Station 1 near the head, Station 2 in the basin just north of Hook Island, Station 3 about $200 \mathrm{~m}$. east of the polynya and Station 4 east of St. Laurent Point (See Table 1). The results from Station 2 showed that the water was almost isothermal at $-1.80^{\circ} \mathrm{C}$, near the

TABLE 1. Details of Stations.

\begin{tabular}{|c|c|c|c|c|}
\hline $\begin{array}{l}\text { Station } \\
\text { Number }\end{array}$ & $\begin{array}{c}\text { Date } \\
\text { and } S \\
\text { time } \\
(\mathrm{GMT})\end{array}$ & $\begin{array}{c}\text { Sounding } \\
\text { in } \\
\text { metres }\end{array}$ & $\begin{array}{c}\text { Ice } \\
\text { thickness } \\
\text { in } \\
\text { metres }\end{array}$ & $\begin{array}{c}\text { Snow } \\
\text { thickness } \\
\text { in } \\
\text { metres }\end{array}$ \\
\hline 1 & $0100,14 / 5$ & 15 & 1.54 & 0.24 \\
\hline 2 & $0150,15 / 5$ & 135 & 1.38 & 0.20 \\
\hline 3 & $0235,16 / 5$ & 7.5 & 0.85 & 0.20 \\
\hline 4 & $0625,22 / 5$ & 225 & 2.02 & 0.40 \\
\hline
\end{tabular}

FIG. 1. Sketch map of the northwest arm of Makinson Inlet showing the position of the polynya observed in May 1973.

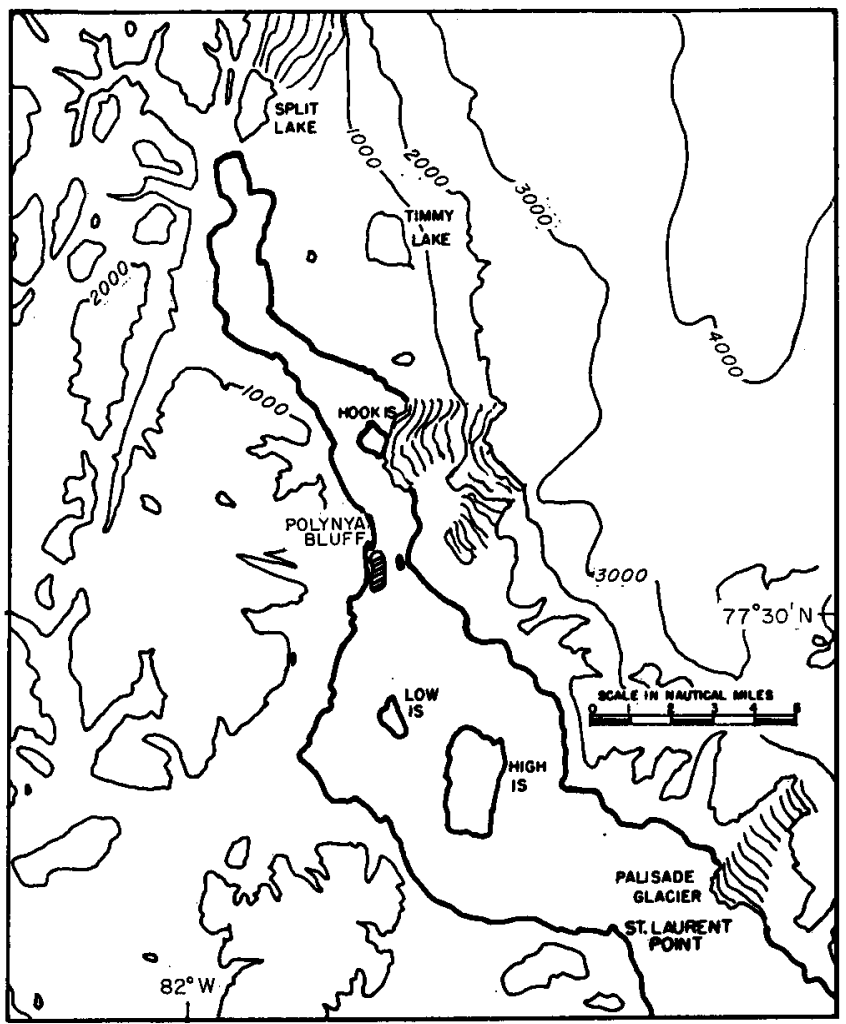




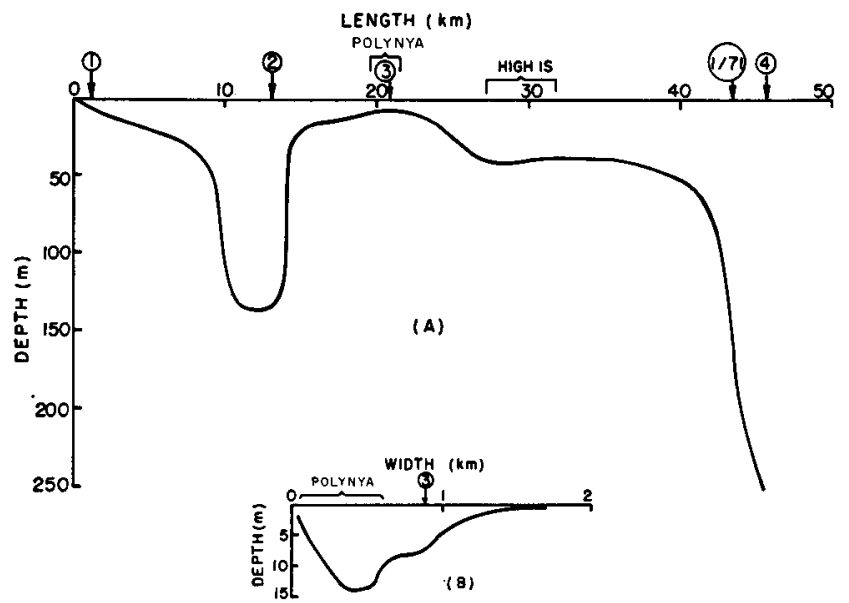

FIG. 2. A. Longitudinal profile of the northwest arm from the head to St. Laurent Point. B. Cross-section of the arm through the polynya.

freezing point, with little salinity variation in the vertical column. The temperature at $125 \mathrm{~m}$. in Station 2 was nearly $0.5^{\circ} \mathrm{C}$ lower than the temperature at the same depth in Station 4 in the waters of the main section of the inlet. A tentative explanation of the homogeneous water structure found in Station 2 and of the existence of the polynya south of Polynia Bluff is suggested below.

It should be noted that none of the names applied to features in the inlet are yet authorized. They are under consideration by the Canadian Permanent Committee on Geographical Names.

Only a small number of soundings taken in the waters north of High Island are available, and the bathymetry shown in Fig. $2 \mathrm{~A}$ is estimated from these soundings, from the general appearance of the morphology and from the appearance of tide-cracks and grounded ice. The resulting estimated volume of water in the inlet is $2.4 \times 10^{9} \mathrm{~m} .{ }^{3}$ which is considered accurate only to within a factor of three. Similarly, the cross-section shown in Fig. 2B was estimated from four soundings taken in May 1973 together with six handlead soundings taken in the polynya area during a very brief visit in August 1973. The estimated cross-sectional area, $1.5 \times 10^{4} \mathrm{~m} .^{2}$ is probably accurate to a factor of 2 . No continuous tidal records have been taken in the inlet, but the tide was observed to be essentially semi-diurnal with a range of about $2 \mathrm{~m}$. The resulting estimate of the volume of the tidal prism is $8.6 \times 10^{7} \mathrm{~m} .{ }^{3}$. Alternatively, tidal velocities in the polynya were estimated by observation of the motion of floating brash ice to be about $1.0 \mathrm{~m} . \mathrm{sec}^{-1}$. For a cross-section of $1.5 \times 10^{4} \mathrm{~m}^{2}$ over a period of six hours, a maximum velocity of $1 \mathrm{~m} . \mathrm{sec}^{-1}$ on a sine-curve tidal form implies a tidal

prism volume of $1.6 \times 10^{8} \mathrm{~m} .^{3}$. The mean value adopted for the volume of the tidal prism, $1.2 \times 10^{8} \mathrm{~m} .{ }^{3}$, is probably accurate to a factor of 2 .

The rate of loss of heat through the surface of the polynya can be estimated ${ }^{1}$ to be about 1000 langleys per day if the air temperature is taken as $-30^{\circ} \mathrm{C}$, the water temperature as $-1^{\circ} \mathrm{C}$ and the mean wind velocity $5 \mathrm{~m}$. sec. ${ }^{-1}$. This gives a total heat loss during each flood tide over the $2 \mathrm{~km} .{ }^{2}$ of the polynya of $5 \times 10^{12}$ calories. It is assumed that more or less complete mixing of the incoming tidal flow and the waters of the arm takes place on each flood tide. This assumption is justified, as a first approximation at least, by the state of homogeneity revealed by temperature and salinity observations. The resulting degree of cooling of the water in the arm would then be $3.0 \times 10^{-3}{ }^{\circ} \mathrm{C}$ on each flood tide. If now it is assumed that the water in the arm had a similar temperature structure to that in the main inlet at the beginning of freeze-up, the difference between the average temperature in the deep basin and that in the main inlet in May must be due to additional cooling of the inflowing water as it passes through the polynya. By integration over the upper 150 $\mathrm{m}$., this mean temperature difference is found to be about $0.2^{\circ} \mathrm{C}$, and therefore under the assumed conditions about 70 tides would be required to give the observed cooling, or about 1000 degree-days.

Using climatological statistics for Eureka Sound, the nearest permanent weather station, it appears that the observed temperature distribution could be expected to occur some time in December. Until this time the polynya would remain open because of the flow on both flood and ebb tides of water above the freezing point. Once the water in the basin 
reached an isothermal condition with the temperature at $-1.7^{\circ} \mathrm{C}$ or lower, it might be expected that the very cold waters of the ebb tide would begin to freeze in the polynya. On each flood tide slightly warmer water mixed upwards from the deeper levels of the main inlet would pass through the polynya but the low temperatures of January and February and the large net heat loss due to radiation would probably be sufficient to keep the surface frozen over.

With the return of the sun in April, the combination of solar heating and of ablation from below by the slightly warmer inflowing water would be expected to open the polynya sometime before the rest of the ice in the inlet broke up. When the observations were made in the middle of May the polynya was about $2 \mathrm{~km}$. long north to south and $1 \mathrm{~km}$. wide. The ice in that region of the arm even at some distance from the open water was about one third the thickness of that in the main inlet and about half the thickness of that in the basin (Table 1). ERTS satellite photographs taken in 1973 show that the polynya opened some time between 4 April and 22 April, at which latter date it had a diameter of about $1 \mathrm{~km}$. The ice cover around it remained continuous until July. No observations of the freeze-up date have been made as infrared photographs of this area are not available.

In summary, the water in the basin is well mixed right to the bottom, although the sill depth is less than $15 \mathrm{~m}$. At the same time the polynya region appears to remain open for most of the year. The conclusion is that the two phenomena are complementary and that the homogeneity of the water is a result of the downward mixing of water cooled in its passage through the polynya. Whether the water behind the sill becomes stratified during the summer and consequently becomes partly deoxygenated at depth remains to be determined. However, it seems probable that even if this happens there is complete regeneration of the deep basin water at least every winter.

A further point which may indicate the regular occurrence of this phenomenon is the abundance of animal life found around the polynya. It was estimated that at least 50 ring seal were using the polynya and polar bear left their tracks within $50 \mathrm{~m}$. of the tents, luckily without pausing to investigate the investigators. A number of wolf, fox and hare tracks were seen, while a dozen or so glaucous gulls and arctic gulls patrolled the open water.

While other cases of polynyas in arctic fiords have been reported 2 it appears that this one has some unusual features and would repay further investigation.

\section{H. Eric Sadler \\ Earth Sciences Division \\ Defence Research Establishment \\ Ottawa, Ontario, Canada \\ REFERENCES}

1Walmsley, J. L. 1966. Ice cover and surface heat fluxes in Baffin Bay. McGill University, Montreal, Manuscript Report no. 2.

2Dunbar, Moira. 1957. Curious open-water feature in the ice at the head of Cambridge Fiord. Proceedings of I.U.G.G., Extrait des Comptes Rendus et Rapports - Assemblée Générale de Toronto, 4, pp. 514-519. 